\title{
EFFECT OF ATORVASTATIN IN LIPID PROFILE CHANGES AND INFLAMMATION MARKER ON DIABETES PATIENT WITH DYSLIPIDEMIA
}

\author{
Wulan Panduwi Melasari ${ }^{1 *}$, Suharjono ${ }^{2}$, Wiwid Samsulhadi ${ }^{3}$ \\ ${ }^{1}$ Clinical Pharmacy Master Program, Faculty of Pharmacy, Universitas Airlangga, Surabaya, Indonesia \\ ${ }^{2}$ Department of Clinical Pharmacy, Faculty of Pharmacy, Universitas Airlangga, Surabaya, Indonesia \\ ${ }^{3}$ Haji Hospital, Surabaya, Indonesia
}

\section{ABSTRACT}

Diabetes is one of the risk factors for cardiovascular disease (CVD). Diabetics patients have 2 to 4 times increased risk of cardiovascular disease compared with non-diabetics. TNF-alpha is a proinflammatory cytokine that can be used to determine the risk of atherosclerosis complications triggered by inflammation in diabetes. Statins are a class of HMG CoA reductase inhibitors that inhibit cholesterol biosynthesis and have pleioropic effects that inhibit the release of inflammatory cytokines like TNF-alpha and stabilize atherosclerotic plaques. This study aims to determine the effect of atorvastatin $20 \mathrm{mg} /$ day for 30 days in reducing the lipid profile and TNF-alpha inflammatory markers in patients with diabetes dyslipidemia. Diabetes patient with dyslipidemia who included the inclusion criteria in this observational prospective cohorts studies treated with atorvastatin for 30 days $(n=19)$. The efficacy of statin therapy was measured by lipid profiles ( $L D L, T G, H D L$, and total cholesterol) and TNF-alpha. The results of the study showed that atorvastatin decreased $40.55 \%$ of LDL levels, $15.34 \%$ of TG levels, and $30.70 \%$ oftotal cholesterol levels which statistically significant $(P<0.05)$. As for HDL, there is an increase of $6.06 \%$ but statistically non-significant $(P>0.05)$. TNF-alpha levels increased by $11.30 \%$ which statistically non-significant $(P>0.05)$. The use of atorvastatin $20 \mathrm{mg}$ for 30 days gave reduction in $L D L$, TG, and total cholesterol and increased in HDL. Atorvastatin does not have a reducing effect on TNF-alpha. There was no correlation between lipid profile changes with TNF-alpha changes.

Keywords: atorvastatin; lipid; TNF-alpha; diabetes; dyslipidemia

\section{ABSTRAK}

Pasien diabetes memiliki 2 sampai 4 kali peningkatan risiko penyakit kardiovaskular dibandingkan dengan non diabetes. Untuk mengetahui risiko terhadap adanya penyakit kardiovaskular dapat dilakukan pemeriksaan petanda inflamasi TNF-alpha yang merupakan sitokin proinflamasi yang dapat memicu terjadinya aterosklerosis. Statin merupakan golongan HMG CoA reductase inhibitor yang menghambat biosintesi kolesterol dan memiliki efek pleioropik sehingga menghambat pengeluaran sitokin inflamasi seperti TNF-alpha dan menstabilisasi plak aterosklerosis. Pada penelitian ini bertujuan untuk mengetahu pengaruh atorvastatin $20 \mathrm{mg}$ /hari selama 30 hari dalam menurunkan profil lipid dan petanda inflamasi TNF-alpha pada pasien diabetes dislipidemia. Pasien DM tipe 2 dengan dislipidemia yang memenuhi kriteria inklusi dilakukan studi observasional prospektif kohort dan mendapat atorvastatin selama 30 hari $(n=19)$. Efektivitas terapi statin diukur melalui pemeriksaan profil lipid ( $L D L, T G, H D L$, dan kolesterol total) dan petanda inflamasi TNF-alpha. Hasil penelitian didapatkan pada terapi atorvastatin terjadi penurunan untuk LDL sebesar 40,55\%, TG 15,34\%, dan kolesterol total 30,70\% yang signifikan secara statistik $(P<0,05)$. Sedangkan untuk HDL, terjadi peningkatan sebesar 6,06\% yang tidak signifikan secara statistik $(P>0,05)$. Untuk nilai TNF-alpha terjadi peningkatan sebesar 11,30\% yang tidak signifikan secara statistik( $P>0,05)$. Dari penelitian ini disimpulkan bahwa pemakaian atorvastatin $20 \mathrm{mg}$ selama 30 hari memberikan penurunan terhadap LDL, $T G$, dan kolesterol total dan terhadap HDL terjadi kenaikan. Atorvastatin tidak memberikan efek penurunan terhadap TNFalpha. Tidak ada korelasi antara perubahan profil lipid dengan perubahan TNF-alpha.

Kata kunci: atorvastatin; lipid; TNF-alpha; diabetes; dislipidemia

Correspondence: Wulan Panduwi Melasari, Clinical Pharmacy Master Program, Faculty of Pharmacy, Universitas Airlangga, Surabaya, Indonesia. E-mail: wulanpanduwi21 @ gmail.comm

pISSN:2355-8393 • eISSN: 2599-056x • doi: 10.20473/fmi.v57i1.26326

- Fol Med Indones. 2020;57:6-10 • Received 7 Feb $2018 \bullet$ Accepted 9 Aug 2018

- Open access under CC-BY-NC-SA license • Available at https://e-journal.unair.ac.id/FMI/ 


\section{INTRODUCTION}

Diabetes mellitus is a group of metabolic diseases with characteristics by hyperglycemia that occurs due to abnormalities of insulin secretion, insulin action or both (PERKENI 2015). Based on the results of basic health research in 2013, diabetes is one of the risk factors for cardiovascular disease (CVD) (Ministry of Health 2013). Diabetic patients have 2 to 4 times increased risk of stroke and cardiovascular disease compared with nondiabetes (Powers 2015). Dyslipidemia in diabetic patients occurs because of insulin resistance that causes lipid disorders. Lipid profiles in patients with type 2 diabetes are usually characterized by hypertriglyceridemia, decreased HDL, and elevated LDL (Wu \& Parhofer 2014).

American Diabetes Association (ADA) recommend the target of LDL level in high-risk diabetic patients with cardiovascular risk factors less then $70 \mathrm{mg} / \mathrm{dl}$. If this target can not be achieved, another alternative is chosen by lowering LDL $30 \%-50 \%$ of initial value. In highrisk patients with cardiovascular risk factors, highintensity statin was used as therapy for more significant LDL reduction (ADA 2017).

One of the therapy used to lower LDL is atorvastatin. Atorvastatin classified as moderate intensity at 10-20 $\mathrm{mg}$ doses and high intensity at 40-80 $\mathrm{mg}$ doses (ADA 2017). In addition, statins have anti-inflammatory, antithrombotic properties, and the ability to stabilize atherosclerotic plaques (Davignon 2004). Statins can decrease the expression and function of molecules on the surface of leukocytes by inhibiting migration and chemotaxis from neutrophils to the endothelium thereby inhibiting the release of proinflammatory cytokines TNF-alpha (Stancu \& Sima 2001). TNF-alpha is a proaterogenic cytokine produced by several cells involved in the process of atherosclerosis including macrophages, endothelial cells and smooth muscle cells (Tousoulis et al 2016).

Atorvastatin has a half-life of 14 hours and has an active metabolite with potent equivalent to its parent compound to inhibit HMG-CoA reductase. The longer actions of atorvastatin providing a greater reduction in cholesterol synthesis (Schachter 2005). This study was conducted to determine the efficacy of atorvastatin 20 $\mathrm{mg}$ to decrease the basic lipid profile in the form of total cholesterol, triglycerides, HDL and LDL and TNF-alpha inflammatory markers in DM patients with dyslipidemia. This study was conducted for 30 days according to the maximum effect of cholesterol and triglyceride reduction in 2-4 weeks of therapy
(American Society of Health System Pharmacist 2011, Lacy et al 2016).

\section{MATERIALS AND METHODS}

This study is a prospective observational study of cohorts. Patients with type 2 diabetes with dyslipidemia in the Internal Medicine Polyclinic of Haji Hospital, Surabaya during November 2017 - January 2018 who included into the inclusion criteria were patients aged $>$ 21-75 years, lipid profiles of LDL > $100 \mathrm{mg} / \mathrm{dL}, \mathrm{TG}>$ $150 \mathrm{mg} / \mathrm{dL}$, did not receive statin therapy 7 days earlier and had signed informed consent. Exclusion criteria from this study were patients with increased liver function tests, patients with severe chronic kidney disease to renal failure, patients receiving antiinflammatory medication, patients with infectious disease, inflammation, malignancy, and autoimmune disease. Examination of LDL, TG, total cholesterol, HDL were performed at General Hajj Hospital Laboratory. TNF-alpha examination using ELISA (Biolegend $\left.{ }^{\circledR}\right)$ methodology was performed at the Infection Specialized Hospital Surabaya. Paired t-test and Wilcoxon test were used to determine differences in lipid, IL6 and TNF-alpha profiles before and after treatment using. The correlation between lipid profile and inflammatory markers TNF-alpha before and after therapy analyse with Pearson correlation test. The result of statistical test is significant if $\mathrm{p}<0,05$ with confidence interval equal to $95 \%$.

\section{RESULTS}

A total of 19 patients who met the inclusion criteria were used as the subjects of the study. Patient demographic data can be seen in table 1. Research subjects consisted of 13 women $(68.42 \%)$ and 6 men (31.58\%), with mainly in $46-59$ years group $(57.89 \%)$ and based on BMI $57.89 \%$ in $18,5-24,9 \mathrm{~kg} / \mathrm{m} 2$ group. The comorbid disease are hypertension 10 patients $(52.63 \%)$ and uric acid 7 patients (31.58\%).

Table 1. Early characteristics of diabetes dyslipidemic patients

\begin{tabular}{llccc}
\hline \multicolumn{2}{c}{ Characteristics of Patients } & $\mathrm{N}$ & $\begin{array}{c}\text { Persentage } \\
(\%)\end{array}$ & $\begin{array}{c}\text { Average } \pm \\
\text { SD }\end{array}$ \\
\hline Gender & Men & 6 & 31.58 & - \\
& Woman & 13 & 68.42 & - \\
\hline Age Range & $26-45$ & 1 & 5.26 & $57.32 \pm$ \\
(years old) & $46-59$ & 11 & 57.89 & 7.94 \\
& $60-74$ & 7 & 36.84 & \\
\hline BMI & $18.5-24.9$ & 11 & 57.89 & $25.44 \pm$ \\
$\left(\mathrm{kg} / \mathrm{m}^{2}\right)$ & $25-29.9$ & 7 & 36.84 & 3.65 \\
& $>30$ & 2 & 10.53 & - \\
\hline Comorbid & Hypertension & 10 & 52.63 & \\
& Uric acid & 7 & 31.58 & \\
\hline
\end{tabular}


There was a reduction of LDL level with mean value of pre $163.47 \pm 28.77 \mathrm{mg} / \mathrm{dL}$ and post $97.89 \pm 29.71$ $\mathrm{mg} / \mathrm{dL}$, reduction of TG with mean value of pre 161.89 $\pm 76.12 \mathrm{mg} / \mathrm{dL}$ and post $132.21 \pm 75.48 \mathrm{mg} / \mathrm{dL}$, and cholesterol total with mean value of pre $232.84 \pm 43.19$ $\mathrm{mg} / \mathrm{dL}$ and post $161.89 \pm 44.73 \mathrm{mg} / \mathrm{dL}$. There was significantly decreased in LDL, TG, and total cholesterol ( $\mathrm{P}<0.05)$, whereas an increase in HDL with a mean value of pre $49.00 \pm 10.75 \mathrm{mg} / \mathrm{dL}$ and post $51.11 \pm 9.28 \mathrm{mg} / \mathrm{dL}$ did not increase significantly $(\mathrm{P}$ $>0.05$ ). Results of TNF-alpha with mean values of pre $9.89 \pm 3.86 \mathrm{pg} / \mathrm{mL}$ and post $161.89 \pm 44.73 \mathrm{pg} / \mathrm{dL}$.

Table 2. Effect of atorvastatin on lipid profile and inflammatory marker TNF-alpha on diabetes patients with dyslipidemia for 30 days

\begin{tabular}{lccccc}
\hline \multicolumn{1}{c}{ Parameter } & \multirow{2}{*}{ Pre } & Post & $\begin{array}{c}\text { Average } \\
\text { Difference }\end{array}$ & $\begin{array}{c}\% \\
\text { Changes }\end{array}$ & Significance \\
\hline LDL (mg/dL) & $163.47 \pm 28.77$ & $97.89 \pm 29.71$ & 65.58 & 40.12 & $0.00^{\mathrm{a}}$ \\
TG (mg/dL) & $161.89 \pm 76.12$ & $132.21 \pm 75.48$ & 29.68 & 15.34 & $0.026^{\mathrm{a}}$ \\
HDL (mg/dL) & $49 \pm 10.75$ & $51.11 \pm 9.28$ & 2.11 & 6.06 & $0.25^{\mathrm{b}}$ \\
Total Cholesterol (mg/dL) & $232.84 \pm 43.19$ & $161.89 \pm 44.73$ & 70.95 & 30.47 & $0.00^{\mathrm{a}}$ \\
TNF-alpha (pg/mL) & $9.89 \pm 3.86$ & $11.01 \pm 4.42$ & 0.79 & 7.09 & $0.49^{\mathrm{a}}$ \\
\hline
\end{tabular}

Table 3. Lipid profile based on NCEP ATP III

\begin{tabular}{|c|c|c|c|c|c|}
\hline \multirow{2}{*}{ Parameter } & \multirow[t]{2}{*}{ Category } & \multicolumn{2}{|c|}{ Pre Therapy } & \multicolumn{2}{|c|}{ Post Therapy } \\
\hline & & Total & $\%$ & Total & $\%$ \\
\hline \multirow{3}{*}{$\begin{array}{c}\text { Total } \\
\text { Cholesterol }\end{array}$} & $\begin{array}{l}\text { Desirable }(<200 \\
\mathrm{mg} / \mathrm{dL})\end{array}$ & 3 & 15.79 & 18 & 94.74 \\
\hline & $\begin{array}{l}\text { Borderline high (200- } \\
239 \mathrm{mg} / \mathrm{dL})\end{array}$ & 10 & 52.63 & - & - \\
\hline & High $(\geq 240 \mathrm{mg} / \mathrm{dL})$ & 6 & 31.58 & 1 & 5.26 \\
\hline \multirow{5}{*}{ LDL } & $\begin{array}{l}\text { Optimal }(<100 \\
\mathrm{mg} / \mathrm{dL})\end{array}$ & - & - & 11 & 57.89 \\
\hline & $\begin{array}{l}\text { Near optimal (100- } \\
129 \mathrm{mg} / \mathrm{dL})\end{array}$ & - & - & 7 & 36.84 \\
\hline & $\begin{array}{l}\text { Borderline high (130- } \\
159 \mathrm{mg} / \mathrm{dL})\end{array}$ & 10 & 52.63 & - & - \\
\hline & $\begin{array}{l}\text { High (160-189 } \\
\mathrm{mg} / \mathrm{dL})\end{array}$ & 7 & 36.84 & - & - \\
\hline & $\begin{array}{l}\text { Very high }(>190 \\
\text { mg/dL) }\end{array}$ & 2 & 10.53 & - & - \\
\hline \multirow{4}{*}{ TG } & $\begin{array}{l}\text { Normal }(<150 \\
\mathrm{mg} / \mathrm{dL})\end{array}$ & 7 & 36.84 & 14 & 73.68 \\
\hline & $\begin{array}{l}\text { Borderline high (150- } \\
199 \mathrm{mg} / \mathrm{dL})\end{array}$ & 9 & 47.37 & 3 & 15.79 \\
\hline & $\begin{array}{l}\text { High (200-499 } \\
\text { mg/dL) }\end{array}$ & 3 & 15.79 & 2 & 10.53 \\
\hline & $\begin{array}{l}\text { Very high }(\geq 500 \\
\text { mg/dL) }\end{array}$ & - & - & - & - \\
\hline \multirow{3}{*}{ HDL } & $<40 \mathrm{mg} / \mathrm{dL}$ & 4 & 21.05 & 1 & 5.26 \\
\hline & $41-59 \mathrm{mg} / \mathrm{dL}$ & 11 & 57.89 & 14 & 73.68 \\
\hline & $\geq 60 \mathrm{mg} / \mathrm{dL}$ & 4 & 21.05 & 4 & 21.05 \\
\hline Total (n) & \multicolumn{5}{|c|}{19 patients } \\
\hline
\end{tabular}

Table 4. Results of correlation test of TNF-alpha changes to lipid profile changes in diabetes dyslipidemic patients

\begin{tabular}{llcc}
\hline & Parameter & $\begin{array}{c}\text { Correlation } \\
\text { coefficient }(\mathrm{r})\end{array}$ & Significance $(\mathrm{p})$ \\
\hline \multirow{5}{*}{ TNF-alpha } & -0.353 & 0.139 \\
& LDL & 0.130 & 0.597 \\
& TG & -0.233 & 0.336 \\
& HDL & 0.032 & 0.896 \\
\hline
\end{tabular}

The results of the correlation analysis showed no correlation between the lipid profile and TNF-alpha $(\mathrm{P}>0.05)$. 


\section{DISCUSSION}

uring the three months of the study period, 20 patients included the inclusion criteria with 1 patient dropped out. Demographic data show the age of diabetics is the most common in 46-59 years as $57.89 \%$ (Table 1). From epidemiological study, patients with diabetes are most commonly by the productive age of between 40-60 years in developing countries (Shaw et al 2010). It was found that hypertension was the most common comorbidity in $52.63 \%$ research subject, followed by $31.58 \%$ of uric acid (Table 2). Hypertension is twice more common in diabetic patients as compared to nondiabetics. Hypertension in diabetics has a persistent BP value of $>=140 / 90 \mathrm{mmHg}$. In the EUROASPIRE IV survey only $54 \%$ of diabetic patients achieved BP levels of less than 140/90 $\mathrm{mmHg}$ (Grossman \& Grossman 2017).

Insulin resistance accompanied by increase free fatty acid into the liver play an important role in increasing the incidence of diabetes dyslipidemia, characterized by high TG concentrations, low HDL concentrations, and high small dense LDL concentrations (Chehade et al 2013). American diabetic association (ADA) and PERKENI recommended that the target lipid profile for patients with diabetes is LDL $<100 \mathrm{mg} / \mathrm{dl} \quad(2.60$ $\mathrm{mmol} / \mathrm{l}), \mathrm{HDL}<40 \mathrm{mg} / \mathrm{dl}(1.02 \mathrm{mmol} / \mathrm{L}$, and $\mathrm{TG}<150$ $\mathrm{mg} / \mathrm{dl}$ (1.7 mmol/l) (ADA 2017, PERKENI 2015).

The NCEP-ATP III Guideline has classified lipid profile based on each levels. Based on guideline, LDL levels are divided into five groups. There is optimal $(<100$ $\mathrm{mg} / \mathrm{dL})$; near optimal (100 - $129 \mathrm{mg} / \mathrm{dL})$; borderline high $(130-159 \mathrm{mg} / \mathrm{dL})$; high $(160-189 \mathrm{mg} / \mathrm{dL})$; and very high $(>=190 \mathrm{mg} / \mathrm{dL})$. TG levels divided into four groups. There is normal $(<150 \mathrm{mg} / \mathrm{dL})$; borderline high $(150-199 \mathrm{mg} / \mathrm{dL})$; high $(200-499 \mathrm{mg} / \mathrm{dL})$ and very high $(>=500 \mathrm{mg} / \mathrm{dL})$ (NCEP-ATP III 2002).

Patients who met the inclusion criteria were measured on the lipid profile before treatment as baseline values. The results of lipid profile from 19 patients showed that for total cholesterol (Table 2) the mean value of pre $232.84 \pm 43.19 \mathrm{mg} / \mathrm{dL}$ and post $161.89 \pm 44.73 \mathrm{mg} / \mathrm{dL}$ decreased by $30.70 \%$. For baseline total cholesterol levels (Table 2) were distributed mainly in borderline high $(200-239 \mathrm{mg} / \mathrm{dl})$ as $52.63 \%$, high $(? 240 \mathrm{mg} / \mathrm{dL})$ as $31.58 \%$.

In the LDL results (Table 2), the mean value of pre $163.47 \pm 28.77 \mathrm{mg} / \mathrm{dL}$ and post $97.89 \pm 29.71 \mathrm{mg} / \mathrm{dL}$ decreased by $40.55 \%$. For baseline values of patients (Table 3) mostly in the high borderline range (130-159 $\mathrm{mg} / \mathrm{dl})$ as $52.63 \%$, high $(160-189 \mathrm{mg} / \mathrm{dl})$ as $36.84 \%$. In diabetic patients there is an increase small dense LDL which more atherogenic that causes risk factor for cardiovascular disease (NCEP-ATP III 2002). For the TG value (Table 2), the mean value of pre $161.89 \pm$ $76.12 \mathrm{mg} / \mathrm{dL}$ and post $132.21 \pm 75.48 \mathrm{mg} / \mathrm{dL}$ decreased by $15.34 \%$. Baseline values of patients (Table 3 ) mostly located in borderline high $(150-199 \mathrm{mg} / \mathrm{dL})$ as $47.37 \%$. For the HDL value (Table 2), the mean value of pre $49.00 \pm 10.75 \mathrm{mg} / \mathrm{dL}$ and post $51.11 \pm 9.25 \mathrm{mg} / \mathrm{dL}$ increased by $6.06 \%$. Baseline values of patients (Table 3) $<40 \mathrm{mg} / \mathrm{dl}$ as $21.05 \%$ and $>=60 \mathrm{mg} / \mathrm{dL}$ as $21.05 \%$.

After 30 days of atorvastatin therapy, there was a change of total cholesterol; desirable range $(<200$ $\mathrm{mg} / \mathrm{dL}$ ) as $94.74 \%$. In the results of LDL, the most patients were found in the optimal range $(<100 \mathrm{mg} / \mathrm{dL})$ as $57.89 \%$ and near optimal $(100-129 \mathrm{mg} / \mathrm{dL})$ as $36.84 \%$. For the TG value, the most patients were in the normal range $(<150 \mathrm{mg} / \mathrm{dL})$ as $68.42 \%$, but there were still patients in the borderline high range (150-199 $\mathrm{mg} / \mathrm{dL})$ as $10.53 \%$ and high $(200-499 \mathrm{mg} / \mathrm{dL})$ as $10.53 \%$. For the HDL values, there are still patients with range $<40 \mathrm{mg} / \mathrm{dL}$ as $5.26 \%$. Based on the change of lipid profile, statistical analysis used a paired t-test for the data before and after therapy with a significant decrease in LDL, TG, and total cholesterol $(\mathrm{P}<0.05)$, but no significant increase in HDL value $(\mathrm{P}>0.05)$.

Based on previous study, ATGOAL showed a decrease in LDL-C targeted at week 4 for low, medium, high-risk patients $(n=1049 / 1246)$ with percentage of patients achieving LDL-C target of $91.9 \%, 87.6 \%$, and $79.2 \%$ for each category with a total of $84.2 \%$ of patients achieving LDL-C target and did not require dose titration (McKenney et al 2005). The Thai ATGOAl study also showed that $81.6 \%$ of patients and $87.1 \%$ of atorvastatin therapy $(n=240)$ had achieved LDL targets at week 2 and 4 (Deerochanawong et al 2007).

Atorvastatin also have pleiotropic effects by inhibiting isoprenoid intermediates such as FPP and GGPP causing obstacles to isoprenyl GTPases such as Ras, Rho, and Rac leading to an inactivated Ras and Rho accumulation in the cytoplasm, where Rac causes an increase in NADPH oxidation causing an increase in ROS (Zhou \& Liao 2010). ROS increases the translocation of NF-kB p65 subunits by transcribing the pro-inflammatory genes MCP-1, Selectin, VCAM-1, and ICAM-1. This event facilitates monocyte adhesion to endothelial vascular, rolling, and diapedeses in subendothel. TNF-a secretions of active macrophages will maintain an increase in adhesion molecules by increasing NF-kB signaling in the endothelium and 
promoting smooth muscle cell growth and proliferation leading to atherosclerosis. Therefore, atorvastatin $20 \mathrm{mg}$ for 30 days is expected to provide pleiotropic effect by inhibiting the release of inflammatory cytokines TNFalpha to prevent atherosclerosis (Paneni et al 2013).

In this study, the mean values of pre TNF-alpha $9.89 \pm$ $3.86 \mathrm{pg} / \mathrm{dL}$ and post $11.01 \pm 4.42 \mathrm{pg} / \mathrm{dL}$ increased by $11.30 \%$ which statistically non-significant $(\mathrm{P}>0.05)$. In the previous study, TNF-alpha values obtained in normal patients were $4.46 \pm 1.42 \mathrm{pg} / \mathrm{dL}$ (Goyal et al 2012). Another study showed TNF-alpha levels were 9.28 (7.56-11.40) pg/dL $(\mathrm{n}=15)$ and 10.02 (5.16-14.69) $\mathrm{pg} / \mathrm{dL}(\mathrm{n}=14)$ in diabetic patients with dyslipidemia (Bellia et al 2010).

Patients who did not achieved fasting glucose and post prandial glucose levels as intended may cause hyperglycaemia. This condition may increase the proportion of FFA that activates TLR resulting in translocation of NF-kB which produced inflammatory cytokines such as TNF-alpha. Increased TNF-alpha may cause a decrease in IRS-1 leading to insulin resistance (Paneni et al 2013).

In obese patients, increased insulin resistance commonly associated with the increased amount of visceral adipose tissue. Abdominal fat tissue has a large lipolysis rate and insulin resistance, resulting in increased free fatty acid production. High free fatty acids will transport to the liver and converted to VLDL and will increase insulin insensitivity. Abdominal fat tissue also triggers an increase in the production of several inflammatory mediators such as TNF-alpha. Inflammatory mediators also contribute to increased peripheral tissue insulin resistance (Triplitt and Reasner 2011).

\section{CONCLUSION}

The results of this study showed that therapy of atorvastatin $20 \mathrm{mg}$ for 30 days reduced LDL, TG, total cholesterol values and increased HDL and TNF-alpha values. There was no correlation between changes in lipid profile values (LDL, TG, total cholesterol, HDL) with TNF-alpha value.

\section{REFERENCES}

American Diabetes Association (2017). Standards of medical care in diabetes. Diabetes Care: The Journal of Clinical and Applied Research and Education 40, supplement 1
American Society of Health System Pharmacist (2011). AHFS Drug Information. Unites States of America

Bellia A, Rizza S, Galli A, Fabiano R, Donadel G, Lombardo MF, Cardillo C, Sbraccia P, Tesauro M, Lauro D (2010). Early vascular and metabolic effects of rosuvastatin compared with simvastatin in patients with type 2 diabetes . Atherosclerosis 210, 199-201

Chehade JM, Gladysz M, Mooradian AD (2013). Dyslipidemia in type 2 diabetes: prevalence, pathophysiology, and management. Drugs 73, 327339

Davignon J (2004). Beneficial cardiovascular pleiotropic effects of statins. Circulation 109, III39-43

Deerochanawong C, Buranakitjaroen P, Nitiyanant W, Suwantamee J, Piamsomboon C, Vongthavaravat V, Suwanwela C, Kosachunhanun N, Sukonthasarn A (2007). The atorvastatin goal achievement across risk levels: (ATGOAL) study in Thailand. J Med Assoc Thai 90, 72-81

Grossman A, Grossman E (2017). Blood pressure control in type 2 diabetic patients. Cardiovascular Diabetology 16, 1-15

Lexicomp (2016). Drug Information Handbook. In: Lacy C, Armstrong L, Goldman M, Lance L (eds). Ohio, Lexi-Comp Inc, p 174-177

Ministry of Health (2013). Badan Penelitian dan Pengembangan Kesehatan Kementrian Kesehatan Republik Indonesia. Jakarta

Paneni F, Beckman JA, Creager MA, Cosentino F (2013). Diabetes and vascular disease: pathophysiology, clinical consequences, and medical therapy: part I. Eur Heart J 34, 2436-2446

PERKENI (2015). Konsensus pengelolaan dan pencegahan diabetes melitus tipe 2 di Indonesia. Jakarta, PB PERKENI, p 1-79

Schachter M (2005). Chemical, pharmacokinetic and pharmacodinamic properties of statin : an update. Fundam Clin Pharmacol 19, 117-125

Shaw JE, Sicree RA, Zimmet PZ (2010). Global estimates of the prevalence of diabetes for 2010 and 2030. Diabetes Res Clin Pract 87, 4-14

Stancu C, Sima A (2001). Statins: mechanism of action and effects. J Cell Mol Med 5, 378-387

Triplitt C, Reasner C (2011). Diabetes mellitus. In: DiPiro J, Talbert RL, Yee G, Matzkee G, Wells B, Posey LM. Pharmacotherapy: a pathophysiologic approach 8th ed, New York, McGraw-Hill

Tousoulis D, Oikonomou E, Economou EK, Crea F, Kaski JC (2016). Inflammatory cytokines in atherosclerosis: current therapeutic approaches. Eur Heart J 37, 1723-1732

Wu L, Parhofer KG (2014). Diabetic dyslipidemia. Metabolism 63, 1469-1479

Zhou Q, Liao JK (2010). Pleiotropic effects of statins: basic research and clinical perspectives. Circ J 74, 818-826 
